FACTA UNIVERSITATIS

Series: Visual Arts and Music Vol. 7, No 1, 2021, pp. 75-85

https://doi.org/10.22190/FUVAM2101075K

Original scientific paper

\title{
VISUAL REPRESENTATIONS OF NATIVE AMERICANS IN COLONIAL AMERICA
}

\author{
UDC $316.647 .8+7.038 .53(=81 /=82)$
}

\section{Ana Kocić Stanković}

Faculty of Philosophy, University of Niš, Serbia

\begin{abstract}
The article presents some of the most common visual representations of Native Americans from the colonial period and the Age of Exploration of the Americas. Visual representations were a part of a broader colonial discourse and were based on the representational practices applied by the dominant Western European culture. After establishing a broader theoretical framework based on the post-colonial and cultural studies insights, the author singles out and analyzes several visual representations of Native Americans. The emphasis is on the Noble vs. Ignoble Savage stereotypes and tropes and how they are reflected in visual arts.
\end{abstract}

Key words: Native Americans, colonial America, stereotypes, visual representations, Cultural studies

\section{INTRODUCTION}

Colonial Americas were the scenes of the first encounters between the Old World and the New World and between (Western) Europeans and Native Americans. Those encounters produced long-lasting representations and images of Native Americans disseminated in high and popular culture and by means of scientific, legal and political discourses. Visual representations of Native Americans often accompanied written narratives and made, perhaps, an even more lasting impression on the European perception of the New World inhabitants. Those images were rooted in stereotypes, prejudices and projections of the Europeans and constituted the discourse of discrimination which was a part of the imperialist agenda.

\footnotetext{
Received January 9, 2021 / Accepted May 12, 2021

Corresponding author: Ana Kocić Stanković

University of Niš, Faculty of Philosophy

Ćirila i Metodija 2, 18000 Niš, Serbia

E-mail: ana.kocic@filfak.ni.ac.rs

${ }^{1}$ The article relies on some of the findings presented in the unpublished thesis of the author The Collective Representations of Minority Groups in the Culture and Literature of Colonial America, defended at the Faculty of Philosophy, University of Nis in 2017 (https://nardus.mpn.gov.rs/handle/123456789/8312).
} 
This paper focuses on visual representations of Native Americans from the early period of the Americas - the Age of Exploration and the Colonial Era. Two notable stereotypes that of the Noble and the Ignoble Savage - are presented and analyzed as two dominant modes and tropes of representation. As visual representations follow the general narrative and the predominant forms of representation, it is first necessary to identify and explain some of the main practices of representation and their underlying mechanisms.

\section{REPRESENTATIONS OF NATIVE AMERICANS IN THE COLONiAL Discourse AND EARLY AMERICA}

Various practices of representing minority group members by the dominant culture constitute the policy of representation. The most common practices in this process are stereotyping and Othering, two concepts that many cultural theorists find very similar as they both involve creating symbolic boundaries between groups and are rooted in the power relations of a society (Pickering, 2001: x-xi).

\subsection{Stereotypes}

Hall (1997, 257-70) identifies several characteristics of stereotyping including: reductionism, Othering, symbolic exclusion, projection, fetishization, all with the purpose of promoting power inequality among groups. Reductionism pertains to the tendency to reduce an entire group to a single set of defining characteristics, usually negative ones (Hall 1992, 308). Those characteristics are represented as fixed and inborn, and, therefore, impossible to change (Ibid.). The usual process is to single out any type of negative behavior observed with some members of minority groups and directly ascribe it to the whole group as a general characteristic, while at the same time, such behaviors of dominant group members are treated as isolated incidents (Shohat and Stam 1994, 183). Stereotyping, thus, helps create symbolic boundaries, effectively stigmatizing and discriminating against those who are perceived and represented as deviant and unacceptable Others (Hall 1997, 257-70).

Another feature of stereotypes is their duality, i.e. representation of minority group members within an "either/or" binary paradigm. A stereotype is often split into two defining characteristics, a good one and a bad one, and they represent mirror images of each other and reduce an entire group to a single defining trait (Hulme 1986, 49-50). Images of Native Americans in colonial and later American literature often exhibited duality - e.g. the tropes of "noble" and "ignoble savage" which were complimentary to each other. An explanation for this mode of representation may lie in the projection of dominant groups' fears, fantasies and negative traits onto the culturally constructed Other (Gilman 1985, 17). These early stereotypes of Native Americans proved to be extremely resilient to change and were disseminated in the later period through some classics of the American literature, popular culture, Hollywood movies, pulp fiction, comic books and even advertisements and commercials (Churchill 2000, 179-85).

Spurr's (1993) and Kocić's (2016) taxonomies of literary tropes of colonization, such as "idealization", "appropriation", "technological superiority", "debasement" and "cultural superiority/inferiority" identify the three main characteristics of the modes of representing colonial Others, namely: reductionism, hierarchical division and debasement. Images of Native Americans often employed the reductive strategy of ascribing characteristics noticed with some members of a particular tribe to all members of all tribes without taking into 
account cultural differences (Berkhofer 1978, 25-7). The natives were often judged by Western European white standards, and always came short. Such criteria usually involved hierarchical division, i.e. the artificial creation of sharp differences between the English colonists and the natives, always favoring the dominant group and representing colonial Others as technologically, civilizationally and culturally inferior. Such binary divisions and tropes of representation fixed the natives into the positions of pupils, immature children or ignorant and poor barbarians. Furthermore, a common practice in the representation of the natives was debasement - a term coined by Gayatri Spivak to denote Othering by ascribing the features of barbarity, bestiality, cruelty, cannibalism and extreme violence to those denoted as Others (Ashcroft et al. 2007, 156-8).

\subsection{Common Tropes of Representation of Native Americans}

A common trope often found in literature and art of conquest and exploration of early America is that of a "Noble Savage" residing in the "Garden of Eden" with the descriptions of intact nature, a bounty of natural resources and of natives' simple lives, uncorrupted by modern society and its "sins" (Hall 1992, 300-5). The concept of the "Noble Savage" as a human "Natural State" was first mentioned by Michel de Montaigne in his essay "Of Cannibals" in the early $17^{\text {th }}$ century. De Montaigne notices and criticizes the modern man's proclivity to mark as "wild" and "barbaric" anything that is not in accordance with the Western European cultural, social and political practices. This "Natural State" is also perceived as civilizationally inferior in comparison with Western Europe. The "Noble Savage" character was first introduced into the English literature by John Dryden, Rousseau analyzed him from the sociological perspective and it quickly entered classical and popular literature and culture, often as an alternative to one's own civilization (Hall 1992, 311-4).

The negative mirror image of the Noble Savage stereotype was the "Ignoble Savage", a degraded, wild, cruel, sometimes even inhuman native, a threat to civilization. This concept was developed by European political philosophers in the $17^{\text {th }}$ and $18^{\text {th }}$ centuries and its basic premise was that the colonial natives were on a lower level of civilizational progress and represented a so-called "childhood of civilization", as termed by John Locke (Hall 1992, 300-5). Many reports from the exploration period mention cannibalism and extreme barbarity explained by a lack of rational capacities in natives. Such representation practices effectively dehumanized the natives and reduced them to mere animals. These reactions of the Old World to the New World were translated into the "pejorative paradigms" which represented Native Americans as savages and monsters, fruits of Western European imagination and fantasy (Vaughan 1995, 53-4). Thus, the original Enlightenment idea of a "Noble Savage" and his limitless potential gave way to the $19^{\text {th }}$-century racist doctrine which emphasized "natural", i.e. unchangeable differences among peoples of different origins and established a hierarchical division based on the notion of civilizational superiority/inferiority (Antlif i Lejten 2004, 284-5). Western literature, culture and art positioned white Europeans and Americans as the desired end of civilizational development, whereas the natives were fixed in the permanent position of "natural" inferiority and backwardness. 


\section{IMAGES OF NATIVE AMERICANS IN COLONIAL AND EARLY AMERICA}

\subsection{Visual and Literary Representations of Native Americans in the Period of Discovery and Exploration}

Since the Age of Discovery, Native Americans were perceived and represented as a single group, regardless of numerous differences among tribes and nations. The first images and representations were the result of the encounters between European explorers and native tribes from South America but they were instrumental in the process of generating knowledge about any other inhabitants of the New World. The functions of the first written accounts of those encounters were mapping the new continents, describing and labeling people, animal and plant species and spreading Western European civilization. A detailed analysis of visual and literary representations reveals their duality: on one hand, the natives were represented as peaceful and hospitable people of impressive physique, and on the other, as treacherous, belligerent and terrifying savages who would have to be conquered by force. Both these modes of representation were a product of a reductionist, stereotyping, binary and exclusive practice of representation.

Columbus' letters and diaries are the first documents and texts in which Native Americans were described as timid and peaceful tribes, technologically and culturally inferior. It is a wellknown fact that Columbus was the first one to use the misnomer "Indians" to refer to the entire group of people - a practice continued by all European explorers and settlers. Columbus (6-8) describes "Indians" as good looking, timid, gullible and naïve. Furthermore, he draws attention to their lack of weapons and advanced technology and claims that they would not pose any threat to the European conquest, especially because they perceive Europeans as superior beings. Promoting Spanish imperialist policy, he claims: "that they might be led to become Christians, and be well inclined to love and serve their Highnesses and the whole Spanish nation, and that they might aid us by giving us things of which we stand in need, but which they possess in abundance" (Columbus, p.8). We can see that Columbus' letters served manifold purposes: from positioning the natives as inferior in their descriptions to supporting a larger Western European discourse of conquest by assuming symbolic power of representation.

Many European artists, engravers and painters often found inspiration in travelers' stories from the New World and produced the first visual images to accompany the imperialist narratives. Theodor de Bry (1528-1598) was one of the best-known engravers famous for his depictions of the New World, its explorers and its inhabitants. His engraving entitled Columbus Landing on Hispaniola from 1594 (Figure 1) contains many of the common tropes of representing Native Americans from the early colonial period. The engraving is visually divided into two portions - the left side depicts the Spanish explorers and the right one the members of the Arawak tribe. The first thing that can be observed is that the Europeans are fully clothed whereas the natives are almost naked only their intimate parts are covered with a cloth. The figure of Columbus is the center of the figure - his confident posture and the spear he holds suggest technological dominance and are in line with the conviction he shows in his Letters. In addition, numerous, impressive-looking Spanish ships and their well-armed soldiers are contrasted with the natives who are shown dancing and running in the background. The implication is that the newcomers are far more impressive, better equipped and better organized - their goal and purpose are well-thought of and precisely executed. On the left, a couple of Spanish soldiers immediately erect a cross as a symbol of their religious mission in the New 
World - spreading Christianity among heathens. The Spanish soldiers are in full armor which signals their conquering intentions. On the other hand, the natives are represented as timid, peaceful and offering gifts to the newcomers. The expressions on their faces clearly show that they are in awe of the Spanish and that they are willing to give their natural riches without resistance. The figures of the natives in the background show them dancing, i.e. not doing anything to transform their natural surroundings. This was an important message conveyed by Columbus' and the colonial narrative: the allegedly superior civilization was entitled to put natural resources of the New World to good use, whereas the natives were represented as lazy, timid and technologically backward. Technological backwardness also implied cultural and civilizational backwardness, which promoted Christian missionary work.

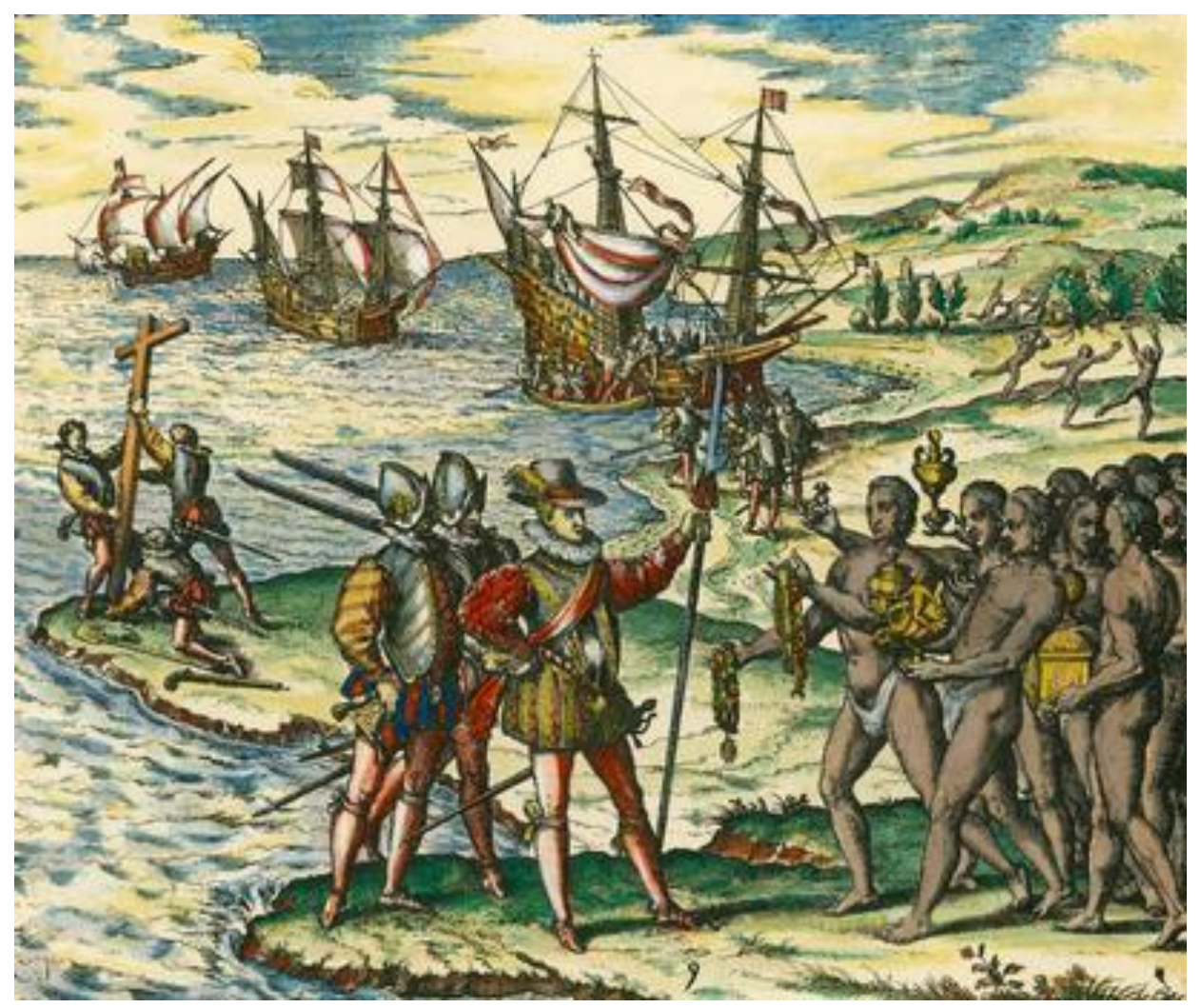

Fig. 1 Columbus Landing on Hispaniola, Theodor de Bry, 1594. (Public domain)

\subsection{The Noble Savage Stereotype}

In the early period of colonization, when it seemed that the natives would not put up much resistance to the European conquest, the predominant image of the natives was that of peaceful savages. As already mentioned, the trope of the Noble Savage was a common representation and the instances of this representation practice can be found in early histories written by English colonizers. One such example is Robert Beverley's History of Virginia from 1705. Beverley claims that Native Americans seemed just and friendly at 
the beginning but later on turned out to be treacherous liars and he warns his contemporaries that "faith is not to be kept with heretics" (p. 44). Beverley describes the physical appearance of the natives in line with the Noble Savage stereotype: he compliments and praises their impressive physique, their athletic build and, especially, the beauty of their women. He insists that he never noticed any physical deformity among Virginian natives and their offspring and perpetuates the images of "Sons and Daughters of Nature". These representations portray Native Americans in a favorable, but nonetheless reductive light.

Beverley's book also contains the illustrations by the English artist John White - visual imagery that follows the narrative. In those figures, Native Americans are represented similar to the ancient Greek and Roman figures of gods and heroes. Figure 2 is an example of that representation practice: two figures, a priest and a conjurer, resemble ancient Greek and Roman statues, well-built, with European facial features. Native Americans are represented through the Noble Savage trope as Beverley claims them to be mythically connected to the classical European cultural heritage. Their surroundings are also represented as friendly, abounding in natural beauty and resources. The implication is that the New World represents "Paradise on Earth", a promised land, which was a common trope in European promotional literature of the Exploration Period.

The purpose of such texts and representations was to promote further settlement and colonization so the New World was portrayed as welcoming, mild, rich and friendly, and its inhabitants as primordial children of civilization. However, it can be said that such modes of representation were more of an expression of Western European projections and fantasies than realistic images. In other words, illustrations from Beverley's book contain common stereotypical tropes of representing Native Americans: reductionism, idealization and fantasy.

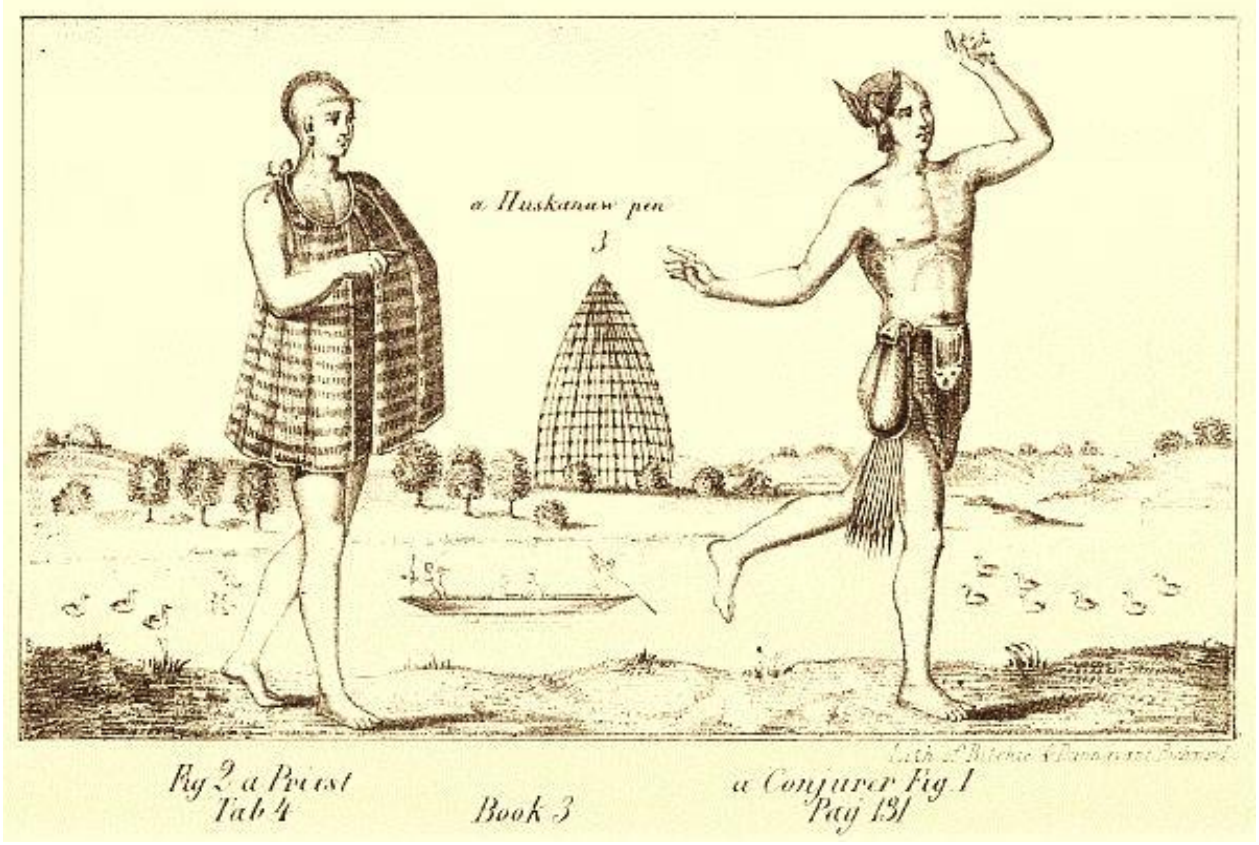

Fig. 2 A Priest and a Conjurer, John White (c. 1540-1593)

(Source: Robert Beverley, The History of Virginia, 1705. Book 3, p. 131) 


\subsection{The Ignoble Savage Stereotype}

A precursor and inspiration for Beverley's History was John Smith's The General History of Virginia, New England and the Summer Isles first published in 1624 republished, corrected and edited many times since and often contested in terms of its veracity (Read, 2005: 21; Olsen-Smith, 2008: 54-5). One of the most often quoted passages from American colonial history, the one describing the encounter of Captain John Smith, a famous English explorer and adventurer and, arguably, the savior of the first English colony Virginia, and the Powhatan tribe, has often been read and analyzed in terms of its portrayal of Native Americans. Captain Smith describes the scene as a horrifying experience where he, captured by the natives, was ordered to put his head between two stones, which he understood as a sacrifice ceremony. Chief Powhatan's daughter, princess Pocahontas threw herself between Smith and the members of her tribe and protected him. Smith described her as his protector and savior and thus gave rise to numerous legends of Pocahontas, many of them still popular today. Later on, many anthropologists interpreted the described scene as an initiation ritual claiming Smith's life was not really in danger (Read, 2005). This scene can also be interpreted in the light of white-Indian relations that followed: misunderstandings on both parts caused by a lack of cultural understanding and leading into conflicts.

Smith's descriptions of Native Americans can be classified into two types: "the good and the bad Indian"; in other words, his images show dual nature. His descriptions of the natives depend on their (in)hostility towards Europeans so those working in favor of the English (later Americans) are described as good, and those opposing the European settlement are described as bad (Jehlen, 1994: 165-7). For example, Smith (2018) describes Pocahontas' brother through the trope of the Noble Savage as "the most manliest, comeliest, boldest spirit", whereas chief Powhatan is described as the Devil incarnate, i.e. the Ignoble Savage.

Smith's history book was accompanied by illustrations, engravings of the English artist Robert Vaughan. Figure 3 shows a set of Vaughan's engravings depicting Smith's adventures among the Powhatan tribes, including the already mentioned episode with Pocahontas. It is first necessary to mention that Smith's history was considered to be an important source of knowledge about the New World, and that it was written and published at the time of establishing the first English colonies in North America, when the natives outnumbered the English settlers by far. This disbalance of power in terms of numbers is visible in Vaughan's illustrations: in all of them except one captain Smith is alone and surrounded by many Powhatan people. Moreover, the figures of Native American chiefs and priests are proportionally much bigger than Smith's figure. The purpose of such representations is to convey the idea of a brave English soldier who single-handedly fights off much stronger attackers. The upper middle figure shows Captain Smith and the Powhatan tribe members around the fire. Fire could be interpreted as a symbol of hell's fire, as well as the figures of Native Americans with animal horns on their heads - a common representation of the devil. Captain Smith is, of course, fully clothed, sitting among them with his hands extended in front of him. This gesture could mean surrender, but also his honesty - the fact that he does not have anything up his sleeve. It is clear that Smith is completely at the mercy of the Powhatans and that is amplified by the three figures marked "A Conjuror", "Their Idol" and "A Priest". These three figures seem to be looming over Captain Smith - just like the natives were considered to be a looming threat to the English colonization. Chief Powhatan 
is represented as an idol, the supreme deity of the heathens and the whole scene is framed to create a sense of fear, anxiety, claustrophobia and impotence in viewers. In other words, those who observe the figure identify with Captain Smith and his own sense of fear and insignificance. The Natives, on the other hand, are represented singing, dancing and rejoicing - their savagery is amplified by their nakedness, their primitive weapons, the food they are eating and their customs.

The scene of Smith's alleged rescue by Pocahontas (the third figure at the bottom) is even more frightful and claustrophobic. Captain Smith is clearly represented as an innocent victim of fearful savages, bound and helpless, tiny and insignificant compared to the figure of Chief Powhatan who is, significantly, seated by the hellish fire. Only the figure of Pocahontas is tinier than Captain Smith which is supposed to emphasize her bravery, but also the savagery of her fellow tribesmen. The European colonizer is in the position of the victim, whereas the power of the Powhatan tribe, at the time of the publication of Smith's book still very solid, is epitomized in the powerful figures of ferocious savages. The fact that there are so many natives and Smith is helpless and completely at their mercy also perpetuates the ignoble savage stereotype.

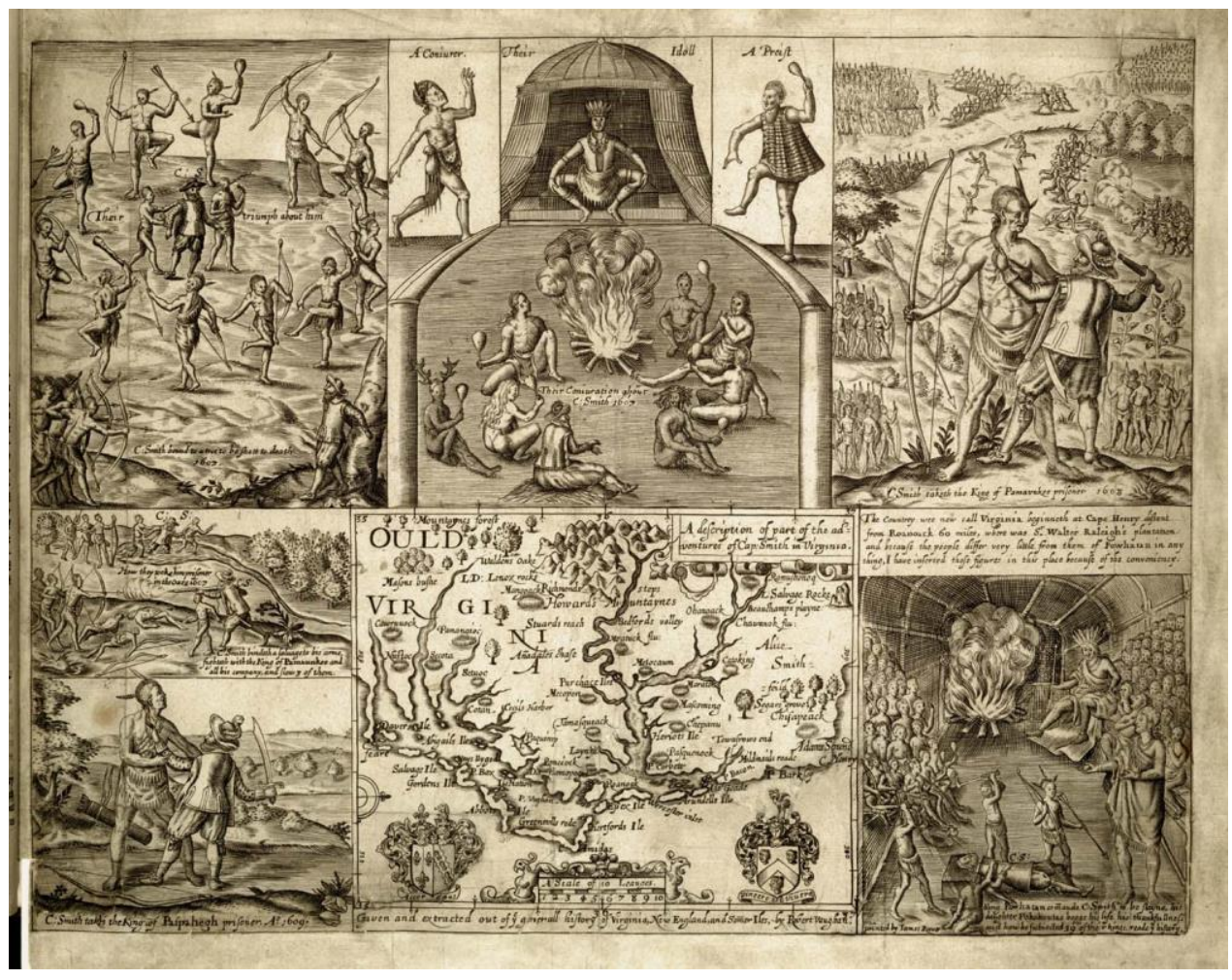

Fig. 3 Ould Virginia A Description of Part of the Adventures of Cap. Smith in Virginia, Robert Vaughan, 1624 (Public Domain) 
The early colonial history of British North America was filled with conflicts and bloodbaths perpetuated by both the colonists and the natives. Another visual representation of the Ignoble Savage stereotype is an engraving by the Swiss artist Matthäus Merian from 1628 (Figure 4). The engraving shows a massacre committed by the Powhatans over early Virginians which happened in 1622. Merian relied on De Bry's depictions of Native Americans and his engraving is entirely based on the stories and figures of the New World of other artists. The Powhatans came to Jamestown on the pretext of starting peace negotiations and were received by the Virginians. However, once they entered Virginian homes, they grabbed tools and weapons they could find and slaughtered an entire village. While it is probably true that the early history of Virginia was full of such events with both sides committing atrocities, this visual representation includes several stereotypical characteristics of Native Americans. Firstly, they are represented as treacherous because they abused the hospitality of their English neighbors and broke the truce. Secondly, they are represented as very cunning and conniving, and finally, they are depicted as ruthless and brutal killers who show no mercy or regret. These representations exhibit all traits of the Ignoble Savage stereotype. A stark contrast between the unsuspecting and shocked expressions on the faces of Virginians and their brutal killers whose postures reveal readiness for an attack can be clearly observed. The engraving also shows women and children begging for mercy amidst the leftovers of the feast in honor of the truce. Similar to the illustrations from Smith's book, this engraving also presents the English as innocent and helpless victims. According to the historians, the true motive for the attack was the fact that the English settlers stole the food that the Powhatans stored for winter (Vaughan, 1979). An implicit message of this visual representation is that peaceful cohabitation with the natives is impossible as they cannot be trusted to respect any agreement, custom or rule of warfare pertaining to the civilians. The cruelty and mercilessness of their facial expressions supports this claim.

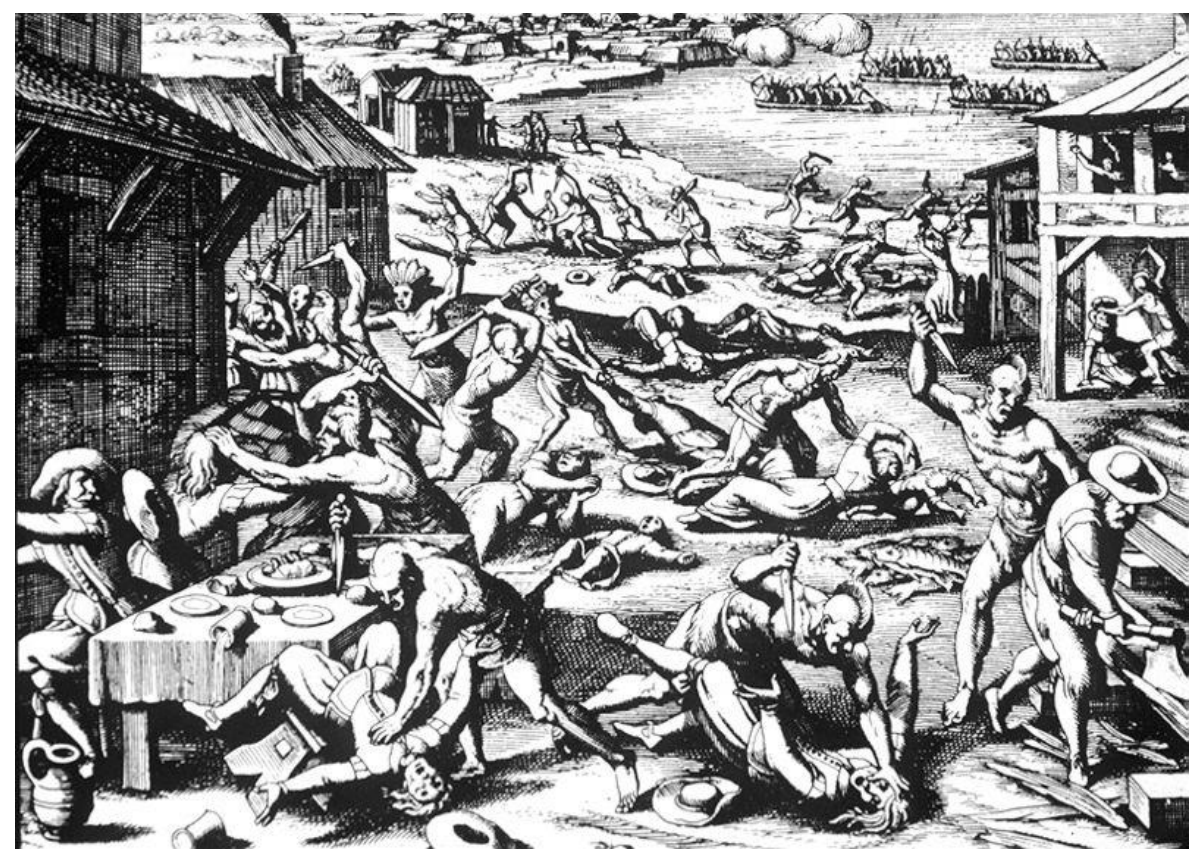

Fig. 4 The 1622 Massacre of Virginia Settlers, Matthaeus Merian, 1628 (Public Domain) 


\section{CONCLUSION}

One of the most important cultural outcomes of the "clash" of cultures that happened in the New World was the lasting perceptions and representations of Native Americans. Two cultural groups, the Europeans and the Native Americans, each with their specific cultural, religious and social beliefs and habits formed opinions and attitudes towards each other. The Western European civilization used its advantage in terms of technology and written language and literature and dominated the new continents economically, culturally and politically. It turned out that the images of Native Americans created and disseminated during the Age of Discovery and the early Colonial Era grew into permanent stereotypes, prejudices and beliefs. What is more, indigenous cultures quickly became marginalized and many of them permanently forgotten. As the colonies and their political power and their territories and inhabitants grew, the representations of Native Americans changed. The initial fascination with the native inhabitants of the New World was replaced by hostility, distrust and hatred epitomized in the predominant stereotypes and visual representations. The trope and the stereotype of the Noble Savage morphed into the Ignoble Savage trope and later into the myth of the Dying Indian. Thus, it can be said that the predominant visual image of the Native American from the analyzed period is that of a bloodthirsty savage and killer.

\section{REFERENCES}

Antlif, M. i P. Lejten, (2004), „Primitivno” U Nelson, R. i Šif, R. (ur.), Kritički termini istorije umetnosti, Svetovi, Novi Sad: pp. 275-293.

Ashcroft, B., Griffiths, G. and H. Tiffin, (2007), Post colonial studies: the key concepts. [e-book], Taylor \& Francis e-Library, London and New York.

Berkhofer, R. 1978. The White Man's Indian: Images of the American Indian from Columbus to the Present. Vintage Books, USA.

Beverley, R., (1705), History of Virginia. Available at: http://www.gutenberg.org/files/32721/32721-h/32721h.htm [05/01/2021]

Churchill, W., (2000), "Literature as a Weapon in the Colonization of the American Indian", In: Hartley, J. and Pearson, R. (eds.) American Cultural Studies: A Reader, UK, OUP, Oxford,: pp. 179-185.

Columbus, C., (1493), Select letters of Christopher Columbus, with other original documents, relating to his four voyages to the New world. Available at: http://www.archive.org/details/selectlettersofc00colurich $[05 / 01 / 2021]$

Gilman, S., (1985), "Black Bodies, White Bodies: Toward an Iconography of Female Sexuality in Late Nineteenth-Century Art, Medicine, and Literature", Critical Inquiry, Vol. 12, No. 1, "Race", Writing, and Difference (Autumn): pp. 204-242.

Hall, S, (1992), "The West and the Rest: Discourse and Power", In: Hall, S.and Gieben, B. (eds.) Formations of Modernity, Polity, Cambridge: pp. 275-332,

Hall, S., (ed.), (1997), Representation: Cultural Representations and Signifying Practices. SAGE Publications \& Open University, London.

Hulme, P., (1986), Colonial Encounters: Europe and the Native Caribbean 1492-1797, Methuen, London.

Jehlen, M., (1994), "The Literature of Colonization". In: Bercovitch, S. (ed.) The Cambridge History of American Literature, Vol. 1: 1590-1820, UK, CUP, Cambridge: pp. 11-168.

Kocić, A., (2016), The Collective Representations of Minority Groups in the Culture and Literature of Colonial America, Unpublished $\mathrm{PhD}$ thesis. https://nardus.mpn.gov.rs/handle/123456789/8312

Montaigne, M. de, (2006), Project Gutenberg's The Essays of Montaigne, Complete [e-book]. Available at: http://www.gutenberg.org/files/3600/3600-h/3600-h.htm [28/ 06/2019].

Olsen-Smith, S., (2008), "Captain John Smith“. In Hayes, K. (Ed). The Oxford Handbook of Early American Literature, UK, OUP, Oxford: pp. 47-67.

Pickering, M., (2001), Stereotyping: the politics of representation., UK, PALGRAVE, Basingstoke, Hampshire. 
Read, D., (2005), New world, known world: shaping knowledge in early Anglo-American writing. University of Missouri Press, Columbia and London.

Shohat, E. and R. Stam, (1994), Unthinking Eurocentrism: Multiculturalism and the Media. Routledge, London. Smith, J., (2018), (1624). The General History of Virginia, New England and the Summer Isles, 1612-1624, Available at: https://www.gutenberg.org/files/56347/56347-h/56347-h.htm [05/01/2021].

Spurr, D., (1993), The Rhetoric of Empire, Duke University Press, London.

Vaughan, A. T., (1979), New England Frontier: Puritans and Indians, 1620-1675, University of Oklahoma Press, Norman, Oklahoma.

Vaughan, A. T., (1995), Roots of American Racism: Essays on the Colonial Experience., Oxford University Press, New York.

\section{VIZUELNE PREDSTAVE O INDIJANCIMA U KOLONIJALNOJ AMERICI}

U članku su predstavljeni neki od najčešćih vizuelnih prikaza američkih Indijanaca iz perioda istraživanja, osvajanja i kolonizacije Amerike. Vizuelne predstave bile su deo šireg kolonijalnog diskursa zasnovane na praksama predstavljanja dominantne većine - zapadnoevropske kulture. Nakon uspostavljanja validnog referentno-teorijskog okvira zasnovanog na uvidima studija kulture i postkolonijalnih studija, autorka izdvaja i analizira nekoliko primera vizuelnih predstava američkih Indijanaca. Posebna pažnja se posvećuje stereotipima i tropima Plemenitog i Krvoločnog Divljaka i načinima na koje su oni predstavljeni u vizuelnoj umetnosti.

Ključne reči: Američki Indijanci, kolonijalna Amerika, stereotipi, vizuelne predstave, studije kulture 